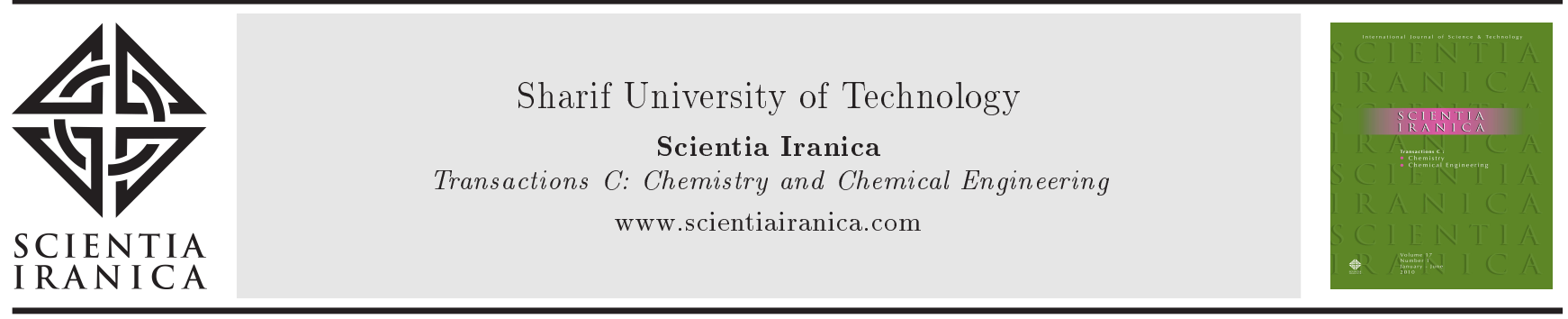

Research Note

\title{
Synthesis of 1, 4-dihydropyridines (DHP) catalyzed by trichloroisocyanuric acid (TCCA) in aqueous media
}

\author{
M. Roknaddini and E. Sheikhhosseini* \\ Department of Chemistry, Kerman Branch, Islamic Azad University, Kerman, P. O. Box 76351-3167, Iran.
}

Received 15 November 2015; received in revised form 19 April 2016; accepted 18 June 2016

\section{KEYWORDS \\ Dihydropyridines; \\ Trichloroisocyanuric \\ acid (TCCA); \\ Three-component \\ reaction; \\ Hantzsch reaction; \\ Aqueous media.}

\begin{abstract}
An array of 1, 4-dihydropyridines (DHP) derivatives was synthesized by Hantzsch three-component reaction of aromatic aldehydes, ethyl acetoacetate, and ammonium acetate using trichloroisocyanuric acid (TCCA) as an efficient catalyst in aqueous media. The proposed method was operationally simple and to make the process benign to the environment, water was used as a reaction medium. No aromatization of dihydropyridines products was done in the presence of TCCA as an oxidant.
\end{abstract}

(C) 2016 Sharif University of Technology. All rights reserved.

\section{Introduction}

Dihydropyridines (DHP) derivatives have been the topic of discussion as they attracted great interest because of their widespread biological characteristics and chemical activity in medicinal and organic chemistry [1]. They are applied as antiatherosclerotic, geroprotective, antitumour, antidiabetic, and hepatoprotective agents [2-4]; anticancer drugs to prevent kinesin motor proteins [5,6]; Rho-kinase inhibitors [7]; anti-HIV drugs [8]; organocatalysts for asymmetric reactions such as asymmetric reductive amination of aldehydes [9], hydrogenation of quinolines in the synthesis of alkaloids [10], and hydrogenation of $\alpha, \beta$ unsaturated aldehydes and ketones $[11,12]$; etc. DHP drugs, which are called nifedipine, nicardipine, and amlodipine, are cardiovascular agents used for the purpose of the treatment of hypertension [13,14].

Providing of 1, 4-DHP was first proposed by Arthur Rudolf Hantzsch in 1881 via a simple one-pot,

\footnotetext{
*. Corresponding author. Tel.: +98 3431321357 ; Fax: +98 3433210051

E-mail address: sheikhhosseiny@gmail.com (E. Sheikhhosseini)
}

three-component condensation reaction of aromatic aldehyde, ammonium acetate, or ammonia and ethyl acetoacetate in acetic acid or by refluxing at the presence of alcohols [15]. Dihydropyridines (DHP) have gained great importance because of their capabilities for synthesis using methods and materials such as microwave irradiation [16], molecular iodine [17], cyanuric chloride [18], $\mathrm{Ga}(\mathrm{OTf})_{3}$ [19], silica gel/ $\mathrm{NaHSO}_{4}$ [20], hydrotalcites (HT) [21], TMSCl-NaI [22], high temperatures $[23,24], \mathrm{InCl}_{3}[25], \mathrm{MgO}$ and $\mathrm{TiO}_{2}$ nanoparticles [26,27], $\mathrm{SiO}_{2} / \mathrm{HClO}_{4}$ [28], CAN [29], melamine trisulfonic acid [30], Na- and Cs-Norit carbons [31], fermenting Baker's yeast [32], $\mathrm{PPh}_{3}$ [33], Candida antarctica lipase $\mathrm{B}$ [34], $\mathrm{Cu}(\mathrm{OTf})_{2}$ [35], $\mathrm{Zr}\left(\mathrm{NO}_{3}\right)_{3}$ [36], fluorinated solvents [37], $\mathrm{ZrOCl}_{2}$ [38], PTSA/SDS [39], $\mathrm{FePO}_{4}[40]$, etc.

Trichloroisocyanuric acid, 1,3,5-trichloro-1,3,5$2,4,6,-(1 \mathrm{H}, 3 \mathrm{H}, 5 \mathrm{H})$-trione (TCCA) was first offered in 1902 by Chattaway and Wadmore (Figure 1) [41].

As it can be seen in the structure stated above, TCCA belongs to the large group of $N$-chloroimides and amides as a subgroup of more general $N$ chloroamines. $N$-chloroamines are inorganic or organic nitrogen compounds with at least one chlorine atom that is attached to nitrogen. Recently, TCCA has 
Table 1. Optimization of reaction condition for the preparation of dihydropyridines (DHPs).

\begin{tabular}{|c|c|c|c|c|c|}
\hline Entry & Catalyst & Solvent & Temperature & Time (min) & Yield $(\%)^{a}$ \\
\hline 1 & TCCA $(25 \%)$ & EtOH & reflux & 50 & 90 \\
\hline 2 & TCCA $(25 \%)$ & $\mathrm{MeOH}$ & reflux & 90 & 52 \\
\hline 3 & TCCA $(25 \%)$ & ETOH: $\mathrm{H}_{2} \mathrm{O}(1: 1)$ & reflux & 55 & 88 \\
\hline 4 & TCCA $(25 \%)$ & $\mathrm{MeOH}: \mathrm{H}_{2} \mathrm{O}(1: 1)$ & reflux & 45 & 82 \\
\hline 5 & TCCA $(25 \%)$ & $\mathrm{H}_{2} \mathrm{O}$ & r.t & 120 & Trace \\
\hline 6 & TCCA $(25 \%)$ & $\mathrm{H}_{2} \mathrm{O}$ & reflux & 30 & 79 \\
\hline 8 & TCCA $(10 \%)$ & EtOH: $\mathrm{H}_{2} \mathrm{O}(1: 1)$ & reflux & 20 & 67 \\
\hline 9 & TCCA $(15 \%)$ & EtOH: $\mathrm{H}_{2} \mathrm{O}(1: 1)$ & reflux & 28 & 70 \\
\hline 10 & TCCA $(25 \%)$ & EtOH: $\mathrm{H}_{2} \mathrm{O}(1: 1)$ & reflux & 55 & 88 \\
\hline 11 & TCCA $(30 \%)$ & EtOH: $\mathrm{H}_{2} \mathrm{O}(1: 1)$ & reflux & 55 & 92 \\
\hline 12 & TCCA $(35 \%)$ & EtOH: $\mathrm{H}_{2} \mathrm{O}(1: 1)$ & reflux & 35 & 70 \\
\hline 13 & TCCA $(40 \%)$ & EtOH: $\mathrm{H}_{2} \mathrm{O}(1: 1)$ & reflux & 80 & 72 \\
\hline
\end{tabular}

a Isolated yield.<smiles>O=c1n(Cl)c(=O)n(Cl)c(=O)n1Cl</smiles>

Figure 1. Trichloroisocyanuric acid.

found much use in organic synthesis. The application of TCCA in organic transformations was extensively reviewed in 2002 and 2007 by Tilstam and Zolfigol $[42,43]$.

In order to continue our effort as a solution to the development of efficient synthetic procedures for multicomponent reactions, we focused on the synthesis of dihydropyridines (DHPs) via the practical synthesis of these compounds using a catalytic amount of TCCA.

\section{Result and discussion}

The main objective of this study was to propose a new catalytic and environmentally benign protocol for the synthesis of new derivatives of $1,4-$ DHPs. $_{\text {s }}$ The researchers used TCCA as a source of $\mathrm{H}^{+}$to catalyze the given reaction and found it a good catalyst for the preparation of dihydropyridines derivatives (Scheme 1).

$25 \mathrm{~mol} \%$ TCCA was employed to catalyze the typical three-component condensation of ethyl acetoac-

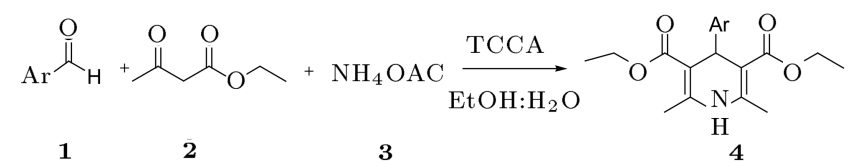

Scheme 1. Synthesis of 1, 4-dihydropyridines (DHP) in the presence of TCCA etate, benzaldehyde, and ammonium acetate under various solvents as collected in Table 1.

As the data in Table 1 reveals, $\mathrm{H}_{2} \mathrm{O}$ produced trace amount of the desired product after $2 \mathrm{~h}$ at room temperature, while in reflux it offered better yields (Table 1, entries 5 and 6). Ethanol can produce the ideal amount of $90 \%$ yield (Table 1, entry 1). The produced yield was recognized to be a little bit lower (88\%) when $\mathrm{H} 2 \mathrm{O}$ was used together with ethanol (Table 1, entry 2). To make the synthesis environmentally beginning, water/ethanol (1:1) solvent system was used as optimized solvent.

Since TCCA was produced as a suitable catalyst for the reaction in 1:1 ethanol/water media, it can be observed that efforts were made to maximize the catalyst load for the three-component reactions, which led to the quick formation of dihydropyridines derivatives. The research on the present optimization revealed that the produced yield increased softly with the catalyst load up to $30 \mathrm{~mol} \%$. The use of greater and lower amounts of the catalyst lowered down the yields (Table 1, entries 12 and 11). However, attention to the proposed mechanism in Scheme 2 reveals that increasing the amount of catalyst (35 and 40\%) may increase the byproducts (1,3,5-triazinane-2,4,6-trione, $\mathrm{H}_{2} \mathrm{O}_{2}$, and Chloroethane) in reaction media and reduce the interaction of starting materials that caused the yield to decrease slowly (entries 12 and 13). A negligible amount of the product was formed in the absence of catalyst.

In order to have control over the viability of this protocol in obtaining a library of 1,4-DHPs derivatives, a sequence of aryl aldehydes was injected to react with ethylacetoacetate and ammonium acetate in the presence of $30 \mathrm{~mol} \%$ of TCCA. The summary of the results are displayed in Table 2 .

As can be seen in Table 2, in all the cases, the 


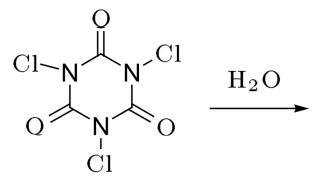

5<smiles>O=C[CH+]C=O</smiles>

6

$$
\begin{gathered}
\mathrm{HClO}+\mathrm{H}_{2} \mathrm{O} \rightarrow \mathrm{H}_{2} \mathrm{O}_{2}+\mathrm{HCl} \\
\mathrm{HClO}+\mathrm{CH}_{3} \mathrm{CH}_{2} \mathrm{OH} \rightarrow \mathrm{H}_{2} \mathrm{O}_{2}+\mathrm{CH}_{3} \mathrm{CH}_{2} \mathrm{Cl}
\end{gathered}
$$

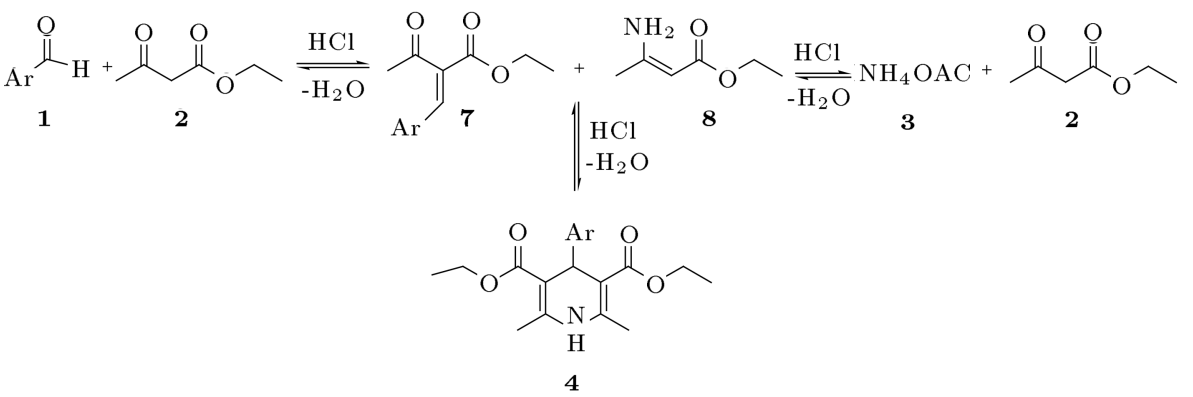

Scheme 2. The proposed mechanism for the synthesis of 1, 4-dihydropyridines using TCCA.

\begin{tabular}{|c|c|c|c|c|c|c|}
\hline \multirow{2}{*}{ Entry } & \multirow{2}{*}{ Ar } & \multirow{2}{*}{$\begin{array}{l}\text { Time } \\
(\min )\end{array}$} & \multirow{2}{*}{ Product } & \multirow{2}{*}{$\begin{array}{l}\text { Yield } \\
(\%)^{a}\end{array}$} & \multicolumn{2}{|c|}{ M.P. $\left({ }^{\circ} \mathrm{C}\right)$} \\
\hline & & & & & Found & Reported \\
\hline 1 & $\mathrm{C}_{6} \mathrm{H}_{5}$ & 55 & $4 \mathrm{a}$ & 92 & $155-158$ & $157-158$ [27] \\
\hline 2 & $2-\mathrm{OH}-\mathrm{C}_{6} \mathrm{H}_{4}$ & 120 & $4 \mathrm{~b}$ & 65 & $230-234$ & $162-163$ [22] \\
\hline 3 & $4-\mathrm{N}(\mathrm{Me})_{2}-\mathrm{C}_{6} \mathrm{H}_{4}$ & 150 & $4 \mathrm{c}$ & 91 & $169-170$ & $207-210$ [22] \\
\hline 4 & $2-\mathrm{MeO}-\mathrm{C}_{6} \mathrm{H}_{4}$ & 40 & $4 \mathrm{~d}$ & 73 & $244-246$ & $172-175[22]$ \\
\hline 5 & $4-\mathrm{MeO}-\mathrm{C}_{6} \mathrm{H}_{4}$ & 155 & $4 \mathrm{e}$ & 65 & $160-161$ & $160-162[27]$ \\
\hline 6 & $2,4-\mathrm{Cl}-\mathrm{C}_{6} \mathrm{H}_{3}$ & 180 & $4 \mathrm{f}$ & 57 & $239-240$ & 241-242 [29] \\
\hline 7 & $3,4,5-(\mathrm{MeO})_{3}-\mathrm{C}_{6} \mathrm{H}_{2}$ & 200 & $4 \mathrm{~g}$ & 70 & $237-240$ & - \\
\hline 8 & $4-\mathrm{NO}_{2}-\mathrm{C}_{6} \mathrm{H}_{4}$ & 180 & $4 \mathrm{~h}$ & 68 & $140-142$ & $129-131$ [27] \\
\hline 9 & $3-\mathrm{NO}_{2}-\mathrm{C}_{6} \mathrm{H}_{4}$ & 165 & $4 \mathrm{i}$ & 53 & $166-168$ & $163-165$ [33] \\
\hline 10 & $3-\mathrm{Cl}-\mathrm{C}_{6} \mathrm{H}_{4}$ & 150 & $4 j$ & 77 & $158-161$ & $141-143$ [31] \\
\hline 11 & $2-\mathrm{Br}-\mathrm{C}_{6} \mathrm{H}_{4}$ & 230 & $4 \mathrm{k}$ & 70 & $248-250$ & $235-236$ [34] \\
\hline 12 & $3-\mathrm{Br}-\mathrm{C}_{6} \mathrm{H}_{4}$ & 180 & 41 & 74 & $259-260$ & $235-236$ [34] \\
\hline 13 & $4-\mathrm{Me}-\mathrm{C}_{6} \mathrm{H}_{4}$ & 180 & $4 \mathrm{~m}$ & 60 & $145-148$ & $136-138[27]$ \\
\hline
\end{tabular}

Table 2. Synthesis of 1, 4-dihydropyridine derivatives catalyzed by TCCA at reflux in water/ethanol.

a Isolated yield.

aromatic aldehydes possessing different substituents (electron-donating or electron-withdrawing groups) were converted into the corresponding products in good yields for good reaction times (40-230 min) under the optimized reaction conditions. The highest yield belonged to $4 \mathrm{a}(92 \%)$ that may be because of the absence of Steric hindrance.

In order to present the efficiency of the selected method, Table 3 compares the results that were achieved in the present study with some of those which were proposed and discussed in the literature.

It has to be noticed that we have not yet been able to produce the mechanism of one-pot three-component reaction between benzaldehyde derivatives, ethyl ace- toacetate, and ammonium acetate in the presence of TCCA; however, the researchers proposed TCCA in water, which produced hypochlorous acid, that reacted with water to form hydrochloric acid and hydrogen peroxide (the structure of 1,3,5-triazinane-2,4,6-trione 6 was deduced from NMR as the byproduct). Knoevenagel reaction occurred in the presence of $\mathrm{HCl}$ via the initial formation of $\alpha, \beta$-unsaturated intermediate 7 by the condensation of protonated aromatic aldehyde with ethyl acetoacetate. Condensation reaction of ethyl acetoacetate in the presence of ammonium acetate and $\mathrm{HCl}$ produced intermediate 8 . Then, Micheal addition of intermediate 7 with 8 followed by cyclization provided the desired product 4 . 
Table 3. Comparison of our results with some of those reported in the literature for the preparation of 1 , 4-dihydropyridines.

\begin{tabular}{|c|c|c|c|c|}
\hline Entry & Reaction condition & Yield (\%) & Time & Ref. \\
\hline 1 & $\mathrm{PPh}_{3}(20 \mathrm{~mol} \%)$, ethanol, reflux & 87 & $2-5 \mathrm{~h}$ & {$[33]$} \\
\hline 2 & Amberlyst-15 $(10 \%, \mathrm{w} / \mathrm{w})$ & 30 & $10 \mathrm{~h}$ & {$[27]$} \\
\hline 3 & $\mathrm{C}_{6} \mathrm{H}_{5} \mathrm{PO}_{2} \mathrm{H}_{2}$ & 45 & $3-4 \mathrm{~h}$ & {$[27]$} \\
\hline 4 & MTSA ( 5 mol $\%$ ), solvent-free & 90 & $3-4 \mathrm{~h}$ & {$[30]$} \\
\hline 5 & $100 \mathrm{mg}$ CAL-B, $0.6 \mathrm{ml} \mathrm{MTBE}, 50^{\circ} \mathrm{C}$ & 71 & $72 \min$ & {$[34]$} \\
\hline 6 & PTSA, SDS, $\mathrm{H}_{2} \mathrm{O}$, r.t. & 65 & $4 \mathrm{~h}$ & [39] \\
\hline 7 & $\mathrm{FePO}_{4}(5 \mathrm{~mol} \%)$, solvent-free, $70^{\circ} \mathrm{C}$ & 78 & $50-75 \min$ & {$[40]$} \\
\hline 8 & TCCA, ethanol-water, reflux & 70 & $2.5 \mathrm{~h}$ & This work \\
\hline
\end{tabular}

It is interesting to note that the use of TCCA/TEA was found to be very efficient for the dehydrogenation of 1,4-dihydropyridines in DMF, such as guanidinium nitrate in the presence of silica sulfuric acid $[42,44]$. But, in this work, no aromatization happened, which might be due to the aqueous media that allowed $\mathrm{HClO}$ to convert into $\mathrm{HCl}$.

In summary, TCCA was found to be a new efficient catalyst for the synthesis of 1,4-dihydropyridines, which was prepared via the condensation reaction of aromatic aldehyde, ethyl acetoacetate, and ammonium acetate using TCCA that was used as a homogenous, neutral, stable, non-volatile, cheap, safe, and commercially available catalyst under aqueous media. All the reactions were carried out and controlled within 1-4 h in water/ethanol and reflux condition. It was felt that column purification of the products was not necessary. General applicability, mild reaction conditions, and environmental benignity were the most important advantages of the procedure used in the study.

\section{Experimental}

\subsection{Materials and methods}

Commercially available starting materials used in this work were procured from Aldrich or Merck Chemical Co. M.P.: Electrothermal-9100 apparatus, uncorrected. IR spectra: Perkin-Elmer FT-IR 240-C spectrophotometer ( $\mathrm{KBr}, \bar{\nu}$ in $\left.\mathrm{cm}^{-1}\right)$. NMR spectra: Varian $400 \mathrm{MHZ}\left({ }^{1} \mathrm{H}\right.$ NMR $)$ and $100 \mathrm{MHz}\left({ }^{13} \mathrm{C} \mathrm{NMR}\right)$ spectrometer using TMS as internal standard and DMSO- $\mathrm{d}_{6}$ as solvent ( $\delta$ in ppm).

\subsection{Synthesis of of 1, 4-dihydorpyridines (DHP) using TCCA: general procedure}

A magnetically stirred solution of ethyl acetoacetate (4 mmol), substituted benzaldehydes (2 mmol), ammonium acetate $(2.2 \mathrm{mmol})$, and TCCA $(0.6 \mathrm{mmol})$ in water and ethanol ( $8 \mathrm{~mL}, 1: 1)$ was refluxed for $1-4 \mathrm{~h}$ for the preparation of 1,4 -dihydorpyridines. The reaction progress was monitored by TLC. When the reaction was complete, the solution was removed under reduced pressure and the solid residue was recrystallized from ethanol. 1,3,5-triazinane-2,4,6-trione $\mathbf{6}$ as by-product was removable by washing with water after evaporation of ethanol. The spectral data of the selected compounds are given below:

\section{Compound 4a: 3-ethyl 5-methyl 1,4-dihydro-2,6-dimethyl-4-phenylpyridine-3, 5-dicarboxylate:}

M.P.: $155-158^{\circ} \mathrm{C}$. IR $\left(\mathrm{KBr}, \mathrm{cm}^{-1}\right): 3342,1688,1650$, 1488. ${ }^{1} \mathrm{H}$ NMR $\left(400 \mathrm{MHz}, \mathrm{DMSO}-d_{6}\right) \delta: 1.13(t, J=$ $7.2 \mathrm{~Hz}, 6 \mathrm{H}, 2 \mathrm{Me}), 2.26$ (s, 6H, 2Me), 3.96-4.00 (m, 4H, $\left.2 \mathrm{CH}_{2}\right), 4.86(\mathrm{~s}, 1 \mathrm{H}, \mathrm{CH}), 7.10-7.20$ (m, 5H, H-Ar), 8.82 $(\mathrm{s}, 1 \mathrm{H}, \mathrm{NH}) \cdot{ }^{13} \mathrm{C}$ NMR $\left(100 \mathrm{MHz}\right.$, DMSO- $\left.d_{6}\right) \delta: 14.2$, 19.5, 39.7, 59.8, 104.1, 126.1, 127.8, 128.0, 144.0, 147.8, 167.7 .

\section{Compound 4p: 3-ethyl 5-methyl}

1,4-dihydro-2,6-dimethyl-4-(3-nitrophenyl) pyridine-3,5-dicarboxylate:

M.P.: $166-168^{\circ} \mathrm{C}$. IR $\left(\mathrm{KBr}, \mathrm{cm}^{-1}\right): 3345,1706,1645$, 1525, 1486, 1347. ${ }^{1} \mathrm{H}$ NMR (400 MHz, DMSO-d 6 ) $\delta$ : $0.88(\mathrm{t}, J=6.8 \mathrm{~Hz}, 6 \mathrm{H}, 2 \mathrm{Me}), 2.05(\mathrm{~s}, 6 \mathrm{H}, 2 \mathrm{Me}), 3.72-$ $3.76\left(\mathrm{~m}, 4 \mathrm{H}, 2 \mathrm{CH}_{2}\right), 4.73(\mathrm{~s}, 1 \mathrm{H}, \mathrm{CH}), 7.30(\mathrm{t}, J=$ $7.6 \mathrm{~Hz}, 51 \mathrm{H}, \mathrm{H}-\mathrm{Ar}), 7.37$ (d, $J=7.2 \mathrm{~Hz}, 1 \mathrm{H}, \mathrm{H}-\mathrm{Ar})$, $7.76(d, J=8.0 \mathrm{~Hz}, 1 \mathrm{H}, \mathrm{H}-\mathrm{Ar}), 7.75$ (s, 1H, H-Ar), $8.77(\mathrm{~s}, 1 \mathrm{H}, \mathrm{NH}) .{ }^{13} \mathrm{C}$ NMR $\left(100 \mathrm{MHz}, \mathrm{DMSO}-d_{6}\right) \delta$ : $14.0,18.2,59.2,101.0,121.0,121.9,129.5,134.2,146.3$, $147.4,150.2,166.5$.

\section{References}

1. (a) Langer, P. "Regio-and diastereoselectivecyclization reactions of free and masked 1, 3-dicarbonyl dianions with 1, 2-dielectrophiles", Chem. Eur. J., 7, pp. 38583866 (2001).

(b) Simon, C., Constantieux, T. and Rodriguez, J. "Utilisation of 1, 3-dicarbonyl derivatives in multicomponent reactions", Eur. J. Org. Chem., 24, pp. 49574980 (2004).

2. Saushins, A. and Duburs, G. "Synthesis of 1, 
4-dihydropyridines by cyclocondensation reactions", Heterocycles, 27, pp. 269-289 (1988).

3. Mager, P.P., Coburn, R.A., Solo, A.J., Triggle, D.J. and Rothe, H. "QSAR, diagnostic statistics and molecular modelling of 1, 4-dihydropyridine calcium antagonists: a difficult road ahead", Drug Des. Discov., 8, pp. 273-289 (1992).

4. Manhold, R., Jablonka, B., Voigdt, W., Schoenfinger, K. and Schravan, E. "Calcium- and calmodulinantagonism of elnadipine derivatives: comparative SAR", Eur. J. Med. Chem., 27, pp. 229-238 (1992).

5. Kappe, C.O., Shishkin, O.V., Uray, G. and Verdino, P. "X-ray structure, conformational analysis, enantioseparation, and determination of absolute configuration of the mitotic kinesin Eg5 inhibitor monastrol", Tetrahedron, 56, pp. 1859-1862 (2000).

6. Huang, Y. and Chen, X. "Carbon nanomaterial-based composites in wastewater purification", Nano LIFE, 4(3), pp. 1441006-1441018 (2014).

7. Goodman, K.B., Cui, H., Dowdell, S.E., Gaitanopoulos, D.E., Ivy, R.L., Sehon, C.A., Stavenger, R.A., Wang, G.Z., Viet, A.Q., Xu, W., Ye, G., Semus, S.F., Evans, C., Fries, H.E., Jolivette, L.J., Kirkpatrick, R.B., Dul, E., Khandekar, S.S., Yi, T., Jung, D.K., Wright, L.L., Smith, G.K., Behm, D.J., Bentley, R., Doe, C.P., Hu, E. and Lee, D. "Development of dihydropyridoneindazole amides as selective Rho-kinase inhibitors", J. Med Chem., 50(1), pp. 6-9 (2007).

8. Huang, Y., Li, J., Chen, X. and Wang, X. "Applications of conjugated polymer based composites in wastewater purification", RSC Adv., 4, pp. 6216062178 (2014).

9. Hoffmann, S., Nicoletti, M. and List, B. "Catalytic asymmetric reductive amination of aldehydes via dynamic kinetic resolution", J. Am. Chem. Soc., 128(40), pp. 13074-13075 (2006).

10. Rueping, M., Antonchick, A.P. and Theissmann, T. "A highly enantioselective Bronsted acid catalyzed cascade reaction: organocatalytic transfer hydrogenation of quinolines and their application in the synthesis of alkaloids", Angew. Chem. Int. Ed., 45, pp. 3683-3686 (2006).

11. Yang, J.W., Fonseca, M.T.H. and List, B. "A metalfree transfer hydrogenation: organocatalytic conjugate reduction of $\alpha, \beta$-unsaturated aldehydes", Angew. Chem. Int. Ed., 43, pp. 6660-6662 (2004).

12. Martin, N.J.A. and List, B. "Highly enantioselective transfer hydrogenation of $\alpha, \beta$-unsaturated ketones", J. Am. Chem. Soc., 128(41), pp. 13368-13369 (2006).

13. Buhler, F.R. and Kiowski, W. "Calcium antagonists in hypertension", J. Hypertension, 5, pp. S3-S10 (1987).

14. Zolfigol, M.A., Salehi, P. and Safaiee, M. "An efficient and eco-friendly procedure for the synthesis of Hantzsch ethyl 1, 4-dihydro-2, 6-dimethylpyridine-3, 5dicarboxylates under mild and green conditions", Lett. Org. Chem., 3, pp. 153-156 (2006).
15. Hantzsch, A. "Ueber die synthese pyridinartiger verbindungen aus acetessigäther und aldehydammoniak", Justus Liebigs Ann. Chem., 215, pp. 1-82 (1882).

16. Anniappan, M., Muralidharan, D. and Perumal, P.T. "Synthesis of Hantzsch 1, 4-dihydropyridines under microwave irradiation", Synth. Commun., 32, pp. 659663 (2002).

17. Ko, S., Sastry, M.N.V., Lin, C. and Yao, C.F. "Molecular iodine-catalyzed one-pot synthesis of 4-substituted-1, 4-dihydropyridine derivatives via Hantzsch reaction", Tetrahedron Lett., 46, pp. 57715774 (2005).

18. Sharma, G.V.M., Reddy, K.L., Lakshmi, P.S. and Krishna, P.R. "In situ'generated $\mathrm{HCl}$ : An efficient catalyst for solvent-free hantzsch reaction at room temperature: Synthesis of new dihydropyridineglycoconjugates", Synthesis, 1, pp. 0055-0058 (2006).

19. Xia, J. and Zhang, K. "Ga (OTf) $)_{3}$ catalyzed synthesis of 1, 4-dihydropyrimidin-2 (1H)-ones", Heterocycles, 91(1), pp. 105-112 (2015).

20. Chari, M.A. and Syamasundar, K. "Silica gel/NaHSO 4 catalyzed one-pot synthesis of Hantzsch 1, 4-dihydropyridines at ambient temperature", Catal. Commun., 6, pp. 624-626 (2005).

21. Antonyraj, C.A. and Kannan, S. "Hantzsch pyridine synthesis using hydrotalcites or hydrotalcite-like materials as solid base catalysts", Applied Catalysis A: General, 338, pp. 121-129 (2008).

22. Sabitha, G., Reddy, G.S.K.K., Reddy, C.S. and Yadav, J.S. "A novel TMSI-mediated synthesis of Hantzsch 1, 4-dihydropyridines at ambient temperature", Tetrahedron Lett., 44, pp. 4129-4131 (2003).

23. Dondoni, A., Massi, A., Minghini, E., Sabbatini, S. and Bertoasi, V. "Synthesis of Hantsch 1, 4-dihydropyridines by fermenting bakers' yeast", J. Org. Chem., 68(16), pp. 6172-6183 (2003).

24. Dondoni, A., Massi, A., Minghini, E. and Bertoasi, V. "Multicomponent Hantzschcyclocondensation as a route to highly functionalized 2-and 4-dihyd- ropyridylalanines, 2-and 4-pyridylalanines, and their N-oxides: preparation via a polymer-assisted solution-phase approach", Tetrahedron, 60, pp. 2311-2326 (2004).

25. Babu, G. and Perumal, P.T. "Synthetic applications of indium trichloride catalyzed reactions", Aldrichim Acta, 33(1), pp. 16-22 (2000).

26. Mirzaei, H. and Davoodnia, A. "Microwave assisted sol-gel synthesis of $\mathrm{MgO}$ nanoparticles and their catalytic activity in the synthesis of hantzsch 1, 4dihydropyridines", Chin. J. Catal., 33, pp. 1502-1507 (2012).

27. Tajbakhshi, M., Alaee, E., Alinezhad, H., Khanian, M., Jahani, F., Khaksar, S., Rezaee, P. and Tajbakhsh, M. "Titanium dioxide nanoparticles catalyzed synthesis of Hantzsch esters and polyhydroquinoline derivatives", Chin. J. Catal., 33, pp. 1517-1522 (2012). 
28. Maheswara, M., Siddaiah, V., Rao, Y.K., Tzeng, Y.M. and Sridhar, C. "A simple and efficient one-pot synthesis of 1, 4-dihydropyridines using heterogeneous catalyst under solvent-free conditions", J. Mol. Catal. A, 260, pp. 179-180 (2006).

29. Ko, S. and Yao, C.F. "Ceric ammonium nitrate (CAN) catalyzes the one-pot synthesis of polyhydroquinoline via the Hantzsch reaction", Tetrahedron, 62, pp. 72937299 (2006).

30. Sheik Mansoor, S., Aswin, K., Logaiya, K. and Sudhan, S.P.N. "Melamine trisulfonic acid as an efficient catalyst for the synthesis of 2, 6-dimet- hy-l4-substituted-1, 4-dihydropyridine-3, 5-diethyl/dimethylcarboxylate derivatives via Hantzsch reaction in solvent free condition", Journal of King Saud University - Science, 25, pp. 191-199 (2013).

31. Perozo-Rondon, E., Calvino-Casilda, V., MartinAranda, R.M., Casal, B., Duran-Valle, C.J. and RojasCervantes, M.L. "Catalysis by basic carbons: Preparation of dihydropyridines", Appl. Surf. Sci., 252, pp. 6080-6083 (2006).

32. Lee, J.H. "Synthesis of Hantsch 1, 4-dihydropyridines by fermenting bakers' yeast", Tetrahedron Lett., 46, pp. 7329-7330 (2005).

33. Debache, A., Ghalem, W., Boulcina, R., Belfaitah, A., Rhouati, S. and Carboni, B. "An efficient one-step synthesis of 1, 4-dihydropyridines via a triphenylphosphine-catalyzed three-component Hantzsch reaction under mild conditions", Tetrahedron Lett., 50, pp. 5248-5250 (2009).

34. Wang, J-L., Liu, B-K., Yin, C., Wu, Q. and Lin, XF. "Synthesis and application of chiral hydrobenzoin", Tetrahedron, 67, pp. 2689-2692 (2011).

35. Paraskar, A.S., Dewkar, G.K. and Sudalai, A. "Cu (OTf $)_{2}$ : A reusable catalyst for high-yield synthesis of 3, 4-dihydropyrimidin-2 (1H)-ones", Tetrahedron Lett., 44, pp. 3305-3308 (2003).

36. Banik, B.K., Reddy, A.T., Datta, A. and Mukhopadhyay, C. "Microwave-induced bismuth nitrate-catalyzed synthesis of dihydropyrimidones via Biginelli condensation under solventless conditions", Tetrahedron Lett., 48, pp. $7392-7394$ (2007).

37. Heydari, A., Khaksar, S., Tajbakhsh, M. and Bijanzadeh, H.R. "One-step, synthesis of Hantzsch esters and polyhydroquinoline derivatives in fluoro alcohols", J. Fluorine Chem., 130, pp. 609-614 (2009).

38. Reddy, C.S. and Nagaraj, A. "Zirconium oxychloride as a new and efficient catalyst for the synthesis of 3 , 4-dihydropyrimidine-2 $(1 \mathrm{H})$-thione/one under solvent- free microwave irradiation conditions", Heterocycl. Commun., 13, pp. 67-72 (2007).

39. Kummer, A. and Maurya, R.A. "Efficient synthesis of Hantzsch esters and polyhydroquinoline derivatives in aqueous micelles", Synlett, 6, pp. 883-885 (2008).

40. Behbahani, F.K. and Yazdanparast, B. "Iron (III) phosphate catalyzed synthesis of 1,4dihydropyridines", Arabian J. Chem. (2014) (In press).

41. Chattaway, F.D. and Wadmore, J.M. "XX.-The constitution of hydrocyanic, cyanic, and cyanuric acids", J. Chem. Soc., 81, pp. 191-203 (1902).

42. Tilstam, U. and Weinmann, H. "Trichloroisocyanuric acid: A safe and efficient oxidant", Organic Process Research \& Development, 6(4), pp. 384-393 (2002).

43. Kolvaria, E., Ghorbani-Choghamaranib, A., Salehic, P., Shirinid, F. and Zolfigol, M.A. "Application of Nhalo reagents in organic synthesis", J. Iran. Chem. Soc., 4(2), pp. 126-174 (2007).

44. Nikoorazm, M. "A new method for the oxidation of 1, 4-dihydropyridine derivatives by guanidinium nitrate in the presence of silica sulfuric acid under mild, heterogeneous and metal-free conditions", Scientia Iranica, Transactions C: Chemistry and Chemical Engineering, 20(30), pp. 603-606 (2013).

\section{Biographies}

Marziyeh Roknaddini was born in 1991 in Bandar Abbas, Iran. She graduated with BSc degree from Islamic Azad University, Kerman Branch, Iran, in 2012, where she carried out her MSc studies. She completed her MSc Thesis under the supervision of Dr. Enayatollah Sheikhhosseini. Her research focuses on the multicomponent reactions and organic methodology.

Enayatollah Sheikhhosseini was born in 1982 in Rabor, Iran. He received his BSc degree from University of Sistan and Baluchestan (Iran) in 2005 and his MSc and PhD degrees from Kharazmi University (Iran) in 2007 and 2011. He completed his doctoral thesis under supervision of professor Saeed Balalaie (Khaje Nasir Toosi University of Technology) and Mohammadali Bigdeli (Kharazmi University). He started his career as a member of Science Groups at Islamic Azad University, Kerman Branch, in 2010, where he is still working. His research interests focus on organic synthesis, multicomponent reactions, and organic methodology. 